IRA-International Journal of Management \&

Social Sciences

ISSN 2455-2267; Vol.17, Issue 02 (Q.2 2021)

Pg. no. 64-70.

IRA Academico Research

\title{
An Evaluation of Adaptive Capability on Organizational Performance of Tier Two Commercial Banks in Kenya
}

\author{
Wambua Benjamin Mweu'\# (D), Maria W. Mung'ara² \\ ${ }^{1}$ Masters of Business Administration, Mount Kenya University, Kenya. \\ 2Lecturer School of Business and Economics, Mount Kenya University, Kenya
}

\#corresponding author

Type of Work: Peer Reviewed.

DOI: https://dx.doi.org/10.21013/jmss.v17.n2.p6

\section{How to cite this paper:}

Mweu, W.B., Mung'ara, M.W. (2021). An Evaluation of Adaptive Capability on Organizational Performance of Tier Two Commercial Banks in Kenya. IRA-International Journal of Management \& Social Sciences (ISSN 2455-2267), 17(2), 64-70. DOI: https://dx.doi.org/10.21013/jmss.v17.n2.p6

(C) IRA Academico Research.

(cc) EY-NC This work is licensed under a Creative Commons Attribution-NonCommercial 4.0 International License subject to a proper citation to the publication source of the work.

Disclaimer: The scholarly papers as reviewed and published by IRA Academico Research are the views and opinions of their respective authors and are not the views or opinions of IRA Academico Research. IRA Academico Research disclaims any harm or loss caused due to the published content to any party.

IRA Academico Research is an institutional publisher member of Publishers International Linking Association Inc. (PILA-CrossRef), USA. IRA Academico Research is an institutional signatory to the Budapest Open Access Initiative. Hungary advocating the open access of scientific and scholarly knowledge. IRA Academico Research is a registered content provider under Open Access Initiative Protocol for Metadata Harvesting (OAI-PMH).

The journal is indexed \& included in WorldCat Discovery Service (USA), CrossRef Metadata Search (USA), WorldCat (USA), OCLC (USA), Open J-Gate (India), EZB (Germany) Scilit (Switzerland), Airiti (China), Bielefeld Academic Search Engine (BASE) of Bielefeld University, Germany, PKP Index of Simon Fraser University, Canada. 


\section{ABSTRACT}

Banking sector rivalry has escalated which can be attributed to many factors including innovation, new legislation, problems caused by a global financial crisis, government regulations, among others that have resulted in increased competition in the banking sector. The objective of this study was to evaluate the influence of adaptive capability on the organizational performance of tier two commercial banks in Kenya. The study found that the application of adaptive capabilities in commercial banks in Kenya is influenced by mainly customer demands, staff expertise and the prevailing market trends. The study results show that there is a positive and statistically significant relationship between Adaptive Capability and performance in tier two banks. The study concluded that adaptive capability has a positive and significant relationship with performance in tier two banks. The research findings recommended that the employees should be fully involved in the decision-making process so that they can own up to the strategies being formulated by the top management.

\section{Introduction}

Keywords: Banking, tier two commercial banks, adaptive capability

\section{Background to the Study}

Today numerous organizations battle to imagine how they would best deal with the assets accessible to offer the best to the market and stay serious. This battle is justifiable, given that expanded legitimate asset use is critical to the company's endurance and competitiveness.

Adaptive capability is defined as a firm's ability to identify and capitalise on emerging market opportunities (Miles \& Snow 1978; Chakravarthy 1982; Hooley et al. 1992). Chakravarthy (1982) distinguishes adaptive capability from adaptation. The latter describes an optimal end state of survival for a firm, while adaptive capability focuses more on the effective search and balancing exploration and exploitation strategies (Staber \& Sydow 2002). This type of 'balancing' act is brought to a strategic level and linked to the resource perspective. Adaptive capability is manifested through strategic flexibility, the inherent flexibility of the resources available to the firm and the flexibility in applying these resources (Sanchez 1995). The development of adaptive capability is often accompanied by the evolution of organizational forms.

While there is writing on the advancement of adaptive capabilities, there appears to be a hole in the research on the proactive adaptive limit. An organization can be imaginative in a reactionary mode (adaptive), or creative in a proactive way (building adaptive limit) so an organization that demonstrates an inventive character could possibly demonstrate adaptive limit. There is a need to shift from considering versatility adjusting for present circumstances or past impacts, to looking forward, visioning, and getting ready to be adaptive and adaptable to address difficulties that have not yet happened. Flexibility can be recognized with continuous learning, instead of a set of skills or resources, and there is a need to study adaptive limits as a continuous learning activity, as opposed to a set of skills. We can consider adjustment as a culture, or method for working together (proactive) versus adjustment as a response to specific, known pressures or changes (receptive).

Empirical studies (e.g. Camuffo \& Volpato 1996; Forrant \& Flynn 1999; Alvarez \& Merino 2003) also reveal that the ability to adapt to environmental changes and align internal resources with external demand is critical to firm evolution and survival in several industries. Firms that have high levels of adaptive capability exhibit dynamic capabilities (Teece et al. 1997). In the existing literature, measures for adaptive capability are multidimensional, including a firm's ability to adapt their product-market scope to respond to external opportunities; to scan the market, monitor customers and competitors and allocate resources to marketing activities; and to respond to changing market conditions in a speedy manner.

In a South African situation, companies were exposed to economic sanctions that limit them from investing offshore (Bhana, 2004). Competition in local investment was high and hence the companies had to invest in strategies in order to cope. Corporate restructuring provided further aggravation which meant that large corporations had to downsize to the effect that they only focused on the core competencies and dynamic capabilities, Ironed by (Oyedijo, 2012).

There has been a rapid technological development in the banking industry in Kenya. Globalization has changed the way banks use technology, information and communication to better serve their customers. More banks are rolling out diverse products with the help of technology in order to meet the client's needs. As the banks become more integrated into the global economy, they are facing opportunities and challenges, Argued (Gitonga, 2012).

Following the 2001 banking crisis in Turkey, the country expedited its reforms for the adoption of diversified measures of regaining the financial power of banks. The tier two commercial banks resorted to the building of 
their dynamic capabilities in order to compete effectively. In contrast to many other countries around the world, universal dynamics in the banking sector have had a less negative effect in Turkey, as stated by Turkmen, \& Yigit, 2012.

\section{Statement of the Problem}

The Central Bank Kenya Report, 2018 revealed that Kenya's business banking segment shows divergences in performance, with certain banks reporting massive benefits while others report misfortunes on their yearly report. Consistently, the financial business has reliably introduced a wide extent of new items driven by expanded competition, ICT advancement and improved client needs which places disparities in the banking segment.

During the past years, players experienced increased competition due to expanded development among the current players and new entrants into the market. The division is additionally battling with the adaption of new guidelines and difficulties enacted by the overall budgetary emergency. In order to remain competitive, the banking sector must adopt strategies to deal with the new emergencies. This study, therefore, sought to evaluate the influence of adaptive capabilities on the organizational performance of tier two banks in Kenya.

\section{Scope of the Study}

The study focused on adaptive capabilities and how they influence the performance of tier two banks in Kenya. The tier two commercial banks are 16 in number as indicated by CBK (2018) report. The unit of analysis was 64 managers from the tier two commercial banks who included the IT Managers, Marketing Managers, Finance Managers and Operations Managers who were best suited to respond on adaptive capabilities.

\section{Dynamic Capability Theory}

The concept of dynamic capability came from the work of Teece et al. (1997). This was in appreciation of the fact that the environment of operation of any given organization changes and hence a firm needs to be agile enough to change as well. As a consequence, there is a need for the firms to have what we call dynamic capabilities to make the process easy.

The theory indicates that a firm needs to be able to integrate its internal resources with the external competencies in order to blend into a strong competitive advantage. There is a need for the firms to blend their various kinds of resources and specialized knowledge into a dynamic capability such as technological capability that can give it dynamism with the changing environment. This theory relates to the banking sector in Kenya which operate in a turbulent environment and the tier two banks must be swift in adapting strategies that will see it competitive under all prevailing circumstances.

\section{Conceptual Framework}

A conceptual framework refers to a figurative connection between study variables based on the concepts derived from reviewed literature (Sullivan, 2011). Figure 1 shows the relationship between the study variable; adaptive capability and organization performance of tier two commercial banks in Kenya

Figure 1: Conceptual Framework

Independent Variables

Adaptive capability
- $\quad$ Retention of resources
- $\quad$ Constant learning

\section{Research Methodology}

This study adopted a Descriptive approach by analysing and explaining the data, characteristics of the entire tier two commercial banks. Research design is a framework that directs research in the process of gathering, evaluating and interpreting observations; the researcher's blueprint for the methods and techniques used to gather and analyse information in order to address the study's questions (Collis \& Hussey, 2013). Descriptive survey research addresses research questions about who, what, where, why, and how is the problem, according to Saunders, Lewis, \& Thornhill (2009).

\section{Dependent variable}

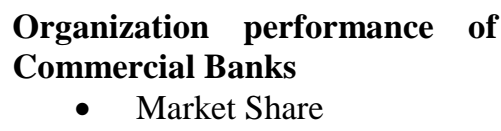




\section{Target Population}

The target population of the study comprised of the 16 tier two commercial banks licensed to operate in Kenya according to the CBK (2018) report. A survey of the entire tier two commercial banks provided a comparison of the levels of adoption of various adaptive capabilities and how they impacted performance. The study targeted managers from the tier two commercial banks that are, IT Managers, Marketing Managers, Finance Managers and Operations Managers so as to establish detailed information on the adapted capabilities. 64 respondents were therefore used for this study.

Table 1: Sample Population

\begin{tabular}{lcc}
\hline Classification & Target Population & Percentage (\%) \\
\hline IT Managers & 16 & 25 \\
Marketing Managers & 16 & 25 \\
Finance Managers & 16 & 25 \\
Operations Managers & 16 & 25 \\
Total & $\mathbf{6 4}$ & $\mathbf{1 0 0}$ \\
\hline
\end{tabular}

Source: Researcher (2019)

\section{Piloting of Research Instruments}

The questionnaire was pre-tested before being used for real data collection. Pre-testing of questionnaires was imperative to stay away from drawbacks in the wake of administering the data collection instrument. Babin (2010) asserts, that pre-testing is a screening approach that requires the researcher to first test the questionnaire on a smaller gathering of respondents so that information and corrections are possible. This technique helped the researcher dispose of erroneous responses because of misinterpretation of questions or blanks in questionnaires because of incomprehension of questions by the respondents.

\section{Reliability of the Research Instrument}

For this analysis, Cronbach alpha was used to test the reliability. Cronbach alpha is an internal consistency measure commonly used on an evaluation tool to determine the correlation values between the answers (Sullivan, 2011). Christensen, Johnson, Turner \& Christensen (2011) Noted that the threshold for Cronbach's Alpha varies among disciplines and the nature of the study. They argued that a value above 0.7 is generally accepted while a value of 0.6 is normally accepted for completely new instruments. The study adopted a Cronbach alpha of 0.7 which is accepted for instruments that are not completely new.

\section{Validity of the Research Instrument}

Invalidity checking, we have to ask whether the questions presented correctly answer the study's objectives. This should include whether the way responses are reported is sufficient or not (Brace, 2013).

In addition, the questionnaire was tested to ensure that there are no errors both typographical and in form. The pilot respondents were allowed to ask questions relating to clarity of the questions which helped the researcher know the validity of questions framed. The feedback from the pilot test formed a basis for reviewing the questionnaire before final administration.

\section{Data Analysis Techniques \& Procedures}

Data were analyzed using descriptive and inferential statistics. The mean, standard deviation was established and regression analysis was done to establish the relationship between the study variables and presented in tables and figures.

\section{Questionnaire Response Rate}

A 93.75\% response rate was achieved for this study from 60 questionnaires which were returned in good time for the study analysis. The response rate was considered adequate for the study to make inferences on the objectives of the study. The findings are presented in Table 2.

Table 2: Questionnaire Response Rate

\begin{tabular}{lcc}
\hline Response Rate & Frequency & Per cent \\
\hline Responses & 60 & 93.75 \\
Non-Response & 4 & 6.25 \\
Total Sample Size & $\mathbf{6 4}$ & $\mathbf{1 0 0 . 0}$ \\
\hline
\end{tabular}

Source: Field Data (2019) 


\section{Adaptive Capability on Performance}

The study sought to establish the influence of adaptive capability on the organisational performance of tier two commercial banks in Kenya. The respondents were asked to indicate their level of agreement on statements on adaptive capability. A scale of 5 to 1 was used to interpret the findings where 5 means that there was strong agreement, 4 is agreed, 3 is Neither agree nor disagree, 2 disagrees and 1 strongly disagrees. The findings are presented in Table 3.

Table 3: Influence of Adaptive Capability on Performance

\begin{tabular}{|c|c|c|}
\hline Adaptive Capability & Mean & Std. Deviation \\
\hline $\begin{array}{l}\text { The organization has invested in Retrieving organizational activities to } \\
\text { unveil the need for change }\end{array}$ & 4.34 & 0.515 \\
\hline $\begin{array}{l}\text { The organization has invested in Variation of existing firms resource } \\
\text { configuration }\end{array}$ & 4.21 & 0.695 \\
\hline $\begin{array}{l}\text { The organization has invested in the Selection of appropriate resource } \\
\text { configuration }\end{array}$ & 4.28 & 0.696 \\
\hline $\begin{array}{l}\text { The organization has invested in the Retention of resources through } \\
\text { the implementation }\end{array}$ & 4.07 & 0.722 \\
\hline The organization has invested in Constant learning & 4.14 & 0.712 \\
\hline The organization has invested Transformation of existing assets & 4.19 & 0.760 \\
\hline Challenges identified are systematically identified and solved. & 4.14 & 0.687 \\
\hline $\begin{array}{l}\text { The organization relies on scientific methods to solve problems rather } \\
\text { than guesswork. }\end{array}$ & 4.16 & 0.721 \\
\hline
\end{tabular}

Source: Field Data (2019)

As shown in Table 3, the respondents agreed that the organizations have invested in Retrieving organizational activities to unveil the need for change (mean score $=4.34$ ); the organizations have invested in the Selection of appropriate resource configuration (mean score $=4.28$ ); and in Variation of existing firms resource configuration (mean score $=4.21$ ). In addition, the respondents agreed that they have invested Transformation of existing assets (mean score $=4.19$ ).

Table 4: Regression Model

\begin{tabular}{lcccc}
\hline Model & R & R Square & Adjusted R Square & Std. Error of the Estimate \\
\hline 1 & $0.850^{\mathrm{a}}$ & 0.722 & 0.680 & 0.18265 \\
a. Predictors: (Constant), Adaptive Capability & & \\
\hline
\end{tabular}

Source: Field Data (2019)

$\mathrm{R}$ is the correlation coefficient that shows the relationship of the variable. The value of $\mathrm{R}$ is 0.850 which shows there is a solid correlation between the variable (adaptive capacity and performance). The value of R square is 0.722 that infers that the autonomous variable (Absorptive Capability) clarifies $72.2 \%$ of the performance of tier two business banks in Kenya. The remaining percentage can be clarified by different factors excluded from the study.

Table 5: ANOVA

\begin{tabular}{llcccc}
\hline \multicolumn{2}{l}{ Model } & Sum of Squares & Mean Square & F & Sig. \\
\hline 1 & Regression & 2.859 & 0.472 & 17.139 & $0.002^{\mathrm{a}}$
\end{tabular}

a. Predictors: (Constant), Adaptive Capability,

b. Dependent Variable: performance.

Source: Field Data (2019)

The ANOVA shows whether there is a statistically significant difference between the variables. The outcomes in Table 4 outlines an $F$ - calculated value $(F=17.139)$ which is significant $(p=0.002<0.05)$. Subsequently, there is a statistically significant difference between adaptive capability and performance. From Significant, the value of 0.002 , means that the regression model is significant and the results can be relied upon. 


\begin{tabular}{|c|c|c|c|c|c|}
\hline \multicolumn{6}{|c|}{ Table 6: Regression Coefficients } \\
\hline \multirow[t]{2}{*}{ Model } & \multicolumn{2}{|c|}{$\begin{array}{l}\text { Unstandardized } \\
\text { Coefficients }\end{array}$} & \multirow{2}{*}{$\begin{array}{c}\text { Standardized } \\
\text { Coefficients } \\
\text { Beta }\end{array}$} & \multirow[t]{2}{*}{$\mathrm{T}$} & \multirow[t]{2}{*}{ Sig. } \\
\hline & $\mathrm{B}$ & $\begin{array}{c}\text { Std. } \\
\text { Error }\end{array}$ & & & \\
\hline (Constant) & 0.157 & 0.783 & & 0.200 & 0.843 \\
\hline Adaptive Capability & 0.234 & 0.062 & 0.371 & 3.751 & 0.002 \\
\hline
\end{tabular}

Dependent Variable: Performance

Source: Field Data (2019)

The study results show that in Table 5, there is a positive and statistically significant relationship between Adaptive Capability and performance in tier two banks as shown by $\beta=0.270$ and $\mathrm{p}=0.002<0.05$.

\section{Summary of Findings}

The study sought to establish the influence of adaptive capability on the organisational performance of tier two commercial banks in Kenya. It was found out that the respondents agreed that adaptive capabilities in commercial banks in Kenya are influenced by customer demands, staff expertise and the prevailing market trends. The regression results established that there is a positive and statistically significant relationship between adaptive capability and performance in tier two banks.

\section{Conclusions}

The study concluded that adaptive capability has a positive and significant relationship with performance in tier two banks. The banks practice the selection of appropriate resource configurations. The banks have also invested in the Retention of resources through implementation. The banks' challenges identified are systematically identified and solved.

\section{Recommendations of the study}

The study recommended that the employees should be fully involved in the decision-making process so that they can own up to the strategies being formulated by the top management. Lack of engagement or involvement of all employees in decision-making can jeopardize the performance of the banks.

The study also recommended that banks should enhance customer retention to enhance and build their customer base, which will consequently lead to improved and better performance in their banks.

\section{ACKNOWLEDGEMENT}

The research was conducted under Research Permit NACOSTI/P/20/7906 that was issued by the National Council of Science, Technology and Innovation (NACOSTI) Nairobi, Kenya.

\section{References}

[1]. Aburub, F. (2015). Impact of ERP systems usage on organization agility: An empirical investigation in the banking sector. Information Technology \& People, 28(3), 570-588.

[2]. Babin, B. J.(2010). Multivariate data analysis: A global perspective (Vol. 7).

[3]. Brace, A. B. (2013). Handbook of survey research. Academic Press.

[4]. Bushuru, N. J., Namusonge, G. S., Oteki, E. B., \& Wandera, R. W. (2014). Factors influencing supply chain performance in the public sugar sector: A Case of Nzoia Sugar Company Limited. International Journal of Recent Research in Commerce Economics and Management (IJRRCEM), 1(3), 18-28.

[5]. Castillo, L.K (2011). Seaport research: A structured literature review on methodological issues since the 1980s. Transportation Research Part A: Policy and Practice, 45(7), 667-685.

[6]. Christensen, L. B., Johnson, B., Turner, L. A., \& Christensen, L. B. (2011). Research methods, design, and analysis.

[7]. DeSarbo, W.S., Di Benedetto, C.A., Song, M. and Sinha, I. (2005) Revisiting the Miles and Snow Framework: Uncovering Interrelationships between Strategic Types, Capabilities, Environmental Uncertainty and Firm Performance. Strategic Management Journal, 26, 47-74. http://dx.doi.org/10.1002/smj.431 
[8]. Dosi, G. (2000). Innovation, organization and economic dynamics: selected essays. Edward Elgar Publishing.

[9]. Forrant, R., \& Flynn, E. (1999). Skills, shop-floor participation and the transformation of Brimfield precision: Lessons for the revitalization of the metalworking sector. Industrial and Corporate Change, 8(1), 167-188.

[10]. Gathungu, J. M \& Mwangi, J. K. (2012). Dynamic Capabilities, Talent Development and Firm Performance. DBA Africa Management Review Journal, 2(3), 83-100.

[11]. Gitonga, C. G. (2012). Factors influencing competitive advantage among commercial banks in Kenya (Masters dissertation, University of Nairobi).

[12]. Kiseli, J. M., Senaji, T. A., \& Eng, R. (2016). Effect of knowledge management capabilities on competitive advantage in the Kenya hospitality industry: The case of five-star hotels in Kenya. International Academic Journal of Human Resource and Business Administration, 2(2), 106129.

[13]. Mugenda, O. M., \& Mugenda, A. (2003). G. (1999). Research Methods in Education.

[14]. Oyedijo, A. (2012). Strategic agility and competitive performance in the Nigerian telecommunication industry: an empirical investigation. American International Journal of Contemporary Research, 2(3), 227-237.

[15]. Miles, R. and Snow, C. (2001) Organizational Strategy, Structure, and Process. The Academy of Management Review, 3, 546-562

[16]. Sullivan, G.M. (2011). A Primer on the Validity of Assessment Instruments. Journal of Business Research

[17]. Tarute, A., \& Gatautis, R. (2014). ICT impact on SMEs performance. Procedia-Social and Behavioral Sciences, $110(0), 1218-1225$.

[18]. Teece, D. J. (2000). Strategies for managing knowledge assets: the role of firm structure and industrial context. Long-range planning, 33(1), 35-54.

[19]. Tuan, N. P., \& Yoshi, T. (2010). Organisational capabilities, competitive advantage and performance in supporting industries in Vietnam. Asian Academy of Management Journal, 15(1). 